\title{
In vitro plant regeneration of Coccinea cordifolia (Linn.) Cogn., an anti-diabetic medicinal plant
}

\author{
Chapol Kumar Roy a, John Liton Munshia ${ }^{\text {, Nadira Begum }}{ }^{\text {, }}$, Rahima Khatun ${ }^{\text {a }}$ \\ and A. K. M. Sayeed Hassan ${ }^{\mathrm{b}}$ * \\ ${ }^{a}$ Biological Research Division, BCSIR Laboratories, Dhaka-1205, Bangladesh. ${ }^{b}$ Department of Botany, Savar \\ College, Savar, Dhaka-1340, Bangladesh
}

\begin{abstract}
An efficient protocol was developed for in vitro plant regeneration of a popularly used anti-diabetic medicinal plant, Coccinea cordifolia (Linn.) Cogn.(Cucurbitaceae) through direct organogenesis using shoot tip and nodal explants. Best shoot induction was observed on MS basal medium supplemented with $0.5 \mathrm{mg} / 1 \mathrm{BAP}$, in which $88.2 \%$ of nodal explants responded to produce maximum number (6.2 \pm 0.58$)$ of shoots per culture. In vitro raised shoots rooted on half strength MS medium with $0.5 \mathrm{mg} / \mathrm{l} \mathrm{IBA}$. The survival rate of regenerated plantlets was $85 \%$.
\end{abstract}

Key words : Coccinea cordifolia, Medicinal plant, Regeneration, Organogenesis, Shoot proliferation, Mass propagation, Acclimatization

\section{Introduction}

Coccinea cordifolia (Linn.) Cogn. commonly known as 'Telakucha' belongs to the family - Cucurbitaceae, a luxuriantly growing tendril climber with cordate, broadly dentate leaves, unisexual funnel-shaped white flowers and smooth oblong fruits, grows commonly in jungles and on hedges all over Bangladesh (Ghani, 2003). Various parts of the plant posses hypoglycemic properties, Ethanolic and aqueous extracts of sun-dried and de-fatted root powder and orally hypoglycemic in rabbits; comparable to tolbutamide and popularly used in the treatment of diabetes; leaves are useful in diabetes in human patients; infusion of the plant parts is also used in anoerexia, epilepsy, catarrh, asthma, fever, dropsy and gonorrhoea (Anonymous, 1989; Ghani, 2003). Leaves are externally used in skin eruptions; plant juice cures ear pain (Ghani, 2003).

In recent years, there has been an increased interest in in vitro culture techniques which offer a viable tool for mass multiplication and germplasm conservation of rare, endangered and threatened medicinal plants (Ajithkumar and Seeni 1998; Prakash et al. 1999). Commercial exploitation and elimination of natural habits consequent to urbanization has led to gradual extinction of several medicinal plants. Micropropagation is an effective approach to conserve such germplasm. In vitro propagation has proven as a potential technology for mass scale production of medicinal plant

*Corresponding author. E-mail:<aksayeedsc@gmail.com> species (Hassan and Roy, 2005; Lui and Li, 2001; Martin 2002, 2003). It is important, therefore, to develop an efficient micropropagation technique for Coccinea cordifolia (Linn.) Cogn. for rapidly disseminate superior clones. There is no report on the establishment of micropropagation protocol for Coccinea cordifolia (Linn.) Cogn. using shoot tip and nodal explants. The present study was therefore, undertaken to develop a protocol for in vitro plant regeneration of a popularly used anti-diabetic medicinal plant, Coccinea cordifolia (Linn.) Cogn. through direct organogenesis using shoot tip and nodal explants.

\section{Materials and Methods}

Coccinea cordifolia (Linn.) Cogn. grown at Medicinal Plants Garden of Bangladesh Council of Scientific and Industrial Research (BCSIR), Dhaka, was used as a source of explants. Shoot tip and nodal explants with a single axillary bud were used for this purpose. The explants were washed thoroughly under running tap water, pre-soaked in liquid detergent for about $30 \mathrm{~min}$, wiped with cotton and dipped in 70\% (v/v) ethanol for $1 \mathrm{~min}$. They were then surface-sterilized with $0.1 \%(\mathrm{w} / \mathrm{v})$ mercuric chloride for $5 \mathrm{~min}$, followed by five times rinse with sterile distilled water under laminar air flow cabinet. The surface-sterilized explants were sized to 1-1.5 $\mathrm{cm}$ length containing a single node with an axillary bud or a 
shoot tip with an apical bud. The explants were placed vertically on the culture medium. The new shoots induced from the in vitro cultures were further used as an explants for adventitious shoot regeneration.

MS (Murashige and Skoog 1962) basal medium was used for shoot proliferation and adventitious shoot regeneration and half strength MS was used for in vitro root induction. All media were supplemented with $30 \mathrm{~g} / 1$ sucrose, $7 \mathrm{~g} / 1$ agar (Difco) and dispensed into $15 \times 150 \mathrm{~mm}$ culture tubes and 250 $\mathrm{ml}$ conical flasks. The $\mathrm{pH}$ of the media was adjusted to 5.8 before autoclaving at $1.9 \mathrm{~kg} / \mathrm{cm}^{2}$ pressure at $121^{\circ} \mathrm{C}$ for 20 min. The cultures were incubated for a $16 \mathrm{~h}$ photoperiod at $24 \pm 2{ }^{\circ} \mathrm{C}$ under $1200 \mathrm{lux} / \mathrm{m}^{2}$ fluorescent light.

Shoot proliferation from shoot tip and nodal explants was obtained in two separate sets of experiments. In the first experiment 0.1-2.0 mg/1 BAP and 0.1-2.0 mg/1 $\mathrm{Kn}$ were incorporated into MS media to select the best cytokinin for the response of shoot induction. In the second set, combination of BAP $(0.5-2.0 \mathrm{mg} / \mathrm{l})$ with NAA $(0.1-0.5 \mathrm{mg} / \mathrm{l})$ and BAP (0.5-2.0 mg/l) with IAA (0.1-0.5 mg/l) were assessed for shoot multiplication. Number of new shoot proliferation of each culture was recorded after every week of inoculation.
For in vitro rooting, individual shoots $(3-5 \mathrm{~cm})$ were excised from the proliferated shoot cultures and implanted on half strength MS media with different concentrations and combinations of NAA, IBA and IAA.

The rooted plants were taken out from the culture tubes, washed to remove agar gel adhered to the roots and transplanted to plastic pots with soil and compost (1: 1) for hardening. The plantlets were kept in a polychamber at $80 \%$ relative humidity, $32 \pm 2{ }^{\circ} \mathrm{C}$ temperatures for a $12 \mathrm{~h}$ photoperiod under $1500 \mathrm{lux} / \mathrm{m}^{2}$ sun light for acclimation. Established plants were transplanted in earthen pots under natural conditions and the survival rate was recorded.

\section{Results and Discussion}

Shoot tip and nodal explants of Coccinea cordifolia (Linn.) Cogn. were cultured on MS media supplemented with various concentration of BAP alone and with NAA or IAA for multiple shoot regeneration. The explants were found to be swollen and they produced two to three shoots within three weeks after inoculation (Fig. 1a) on MS media containing BAP alone but the number of shoots increased up to $6.2 \pm$ 0.58 when the explants were cultured in MS with $0.5 \mathrm{mg} / \mathrm{l}$ BAP (Table I, Fig. 1b). Both the explants responded in the

Table I: $\quad$ Effect of different growth regulators (BAP, NAA and IAA) in MS on morphogenic response of Coccinea cordifolia (Linn.) Cogn. shoot tips and nodal explants

\begin{tabular}{lcccccc}
\hline \multicolumn{2}{c}{ Growth regulators (mg/l) } & \multicolumn{2}{c}{ shoot tips } & \multicolumn{2}{c}{ nodal explants } \\
\hline BAP & NAA & IAA & $\begin{array}{c}\text { \% of explants form- } \\
\text { ing shoots }\end{array}$ & $\begin{array}{c}\text { Mean No. of } \\
\text { Shoot/explant }\end{array}$ & $\begin{array}{c}\text { \% of explants form- } \\
\text { ing shoots }\end{array}$ & $\begin{array}{c}\text { Mean No. of } \\
\text { Shoot/explant }\end{array}$ \\
\hline 0.1 & & $53.4 \pm 0.87$ & $2.0 \pm 0.77$ & $58.6 \pm 1.70$ & $3.4 \pm 0.91$ \\
0.3 & & $62.6 \pm 1.66$ & $3.2 \pm 0.63$ & $67.4 \pm 0.51$ & $4.6 \pm 0.66$ \\
0.5 & & $72.4 \pm 2.89$ & $4.8 \pm 0.92$ & $88.2 \pm 2.80$ & $6.2 \pm 0.58$ \\
1.0 & & $63.4 \pm 1.57$ & $3.6 \pm 0.45$ & $71.4 \pm 2.38$ & $4.6 \pm 0.72$ \\
1.5 & & $57.6 \pm 2.16$ & $2.4 \pm 0.72$ & $67.6 \pm 2.16$ & $3.4 \pm 1.18$ \\
2.0 & & $34.8 \pm 2.58$ & $1.8 \pm 0.76$ & $33.6 \pm 1.84$ & $2.4 \pm 0.82$ \\
0.5 & 0.1 & & $61.4 \pm 2.87$ & $3.2 \pm 0.59$ & $68.6 \pm 1.70$ & $4.6 \pm 1.14$ \\
1.0 & 0.2 & & $42.6 \pm 0.87$ & $2.6 \pm 0.77$ & $43.6 \pm 0.51$ & $3.6 \pm 0.91$ \\
1.5 & 0.5 & & $28.2 \pm 1.66$ & $2.0 \pm 0.63$ & $41.2 \pm 2.47$ & $2.4 \pm 0.66$ \\
2.0 & 0.5 & & $22.2 \pm 1.96$ & $1.4 \pm 0.45$ & $32.2 \pm 0.66$ & $1.8 \pm 0.95$ \\
0.5 & & 0.1 & $48.8 \pm 1.77$ & $3.0 \pm 0.39$ & $56.8 \pm 2.14$ & $4.2 \pm 0.76$ \\
1.0 & & 0.2 & $26.6 \pm 1.66$ & $2.6 \pm 0.65$ & $47.6 \pm 2.10$ & $3.2 \pm 0.51$ \\
1.5 & & $21.0 \pm 1.14$ & $2.2 \pm 0.45$ & $32.6 \pm 1.63$ & $2.4 \pm 0.91$ \\
2.0 & 0.5 & $18.4 \pm 1.96$ & $1.6 \pm 0.76$ & $24.2 \pm 2.47$ & $1.8 \pm 0.76$ \\
\hline
\end{tabular}

Results are mean $\pm \mathrm{SE}$ of three experiments with 15 replications. 

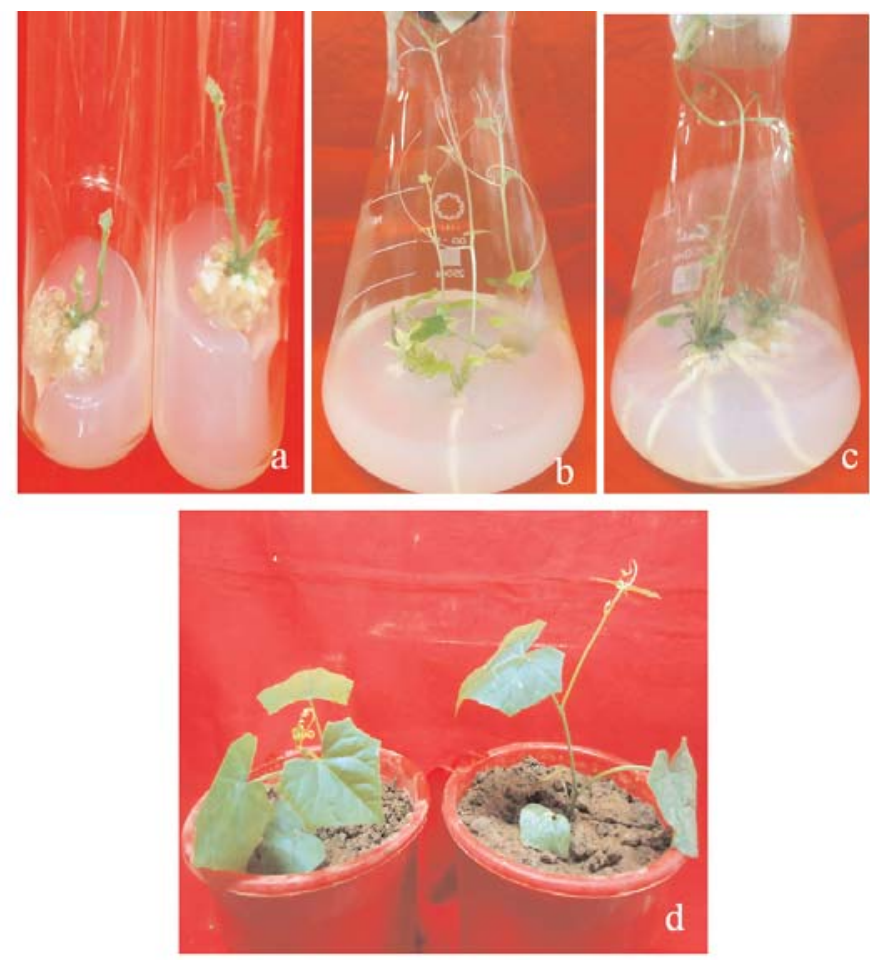

Fig 1: In vitro regeneration of Coccinea cordifolia

(Linn.) Cogn. from nodal explants

(a) Induction of shoots from nodal explants on MS $+0.5 \mathrm{mg} / \mathrm{l} \mathrm{BAP}$ in three weeks of culture.

(b) Development and multiplication of shoots from nodal explants on $\mathrm{MS}+0.5 \mathrm{mg} / \mathrm{l} \mathrm{BAP}$ after six weeks of culture.

(c) Rooting of in vitro regenerated shoots cultured on half strength MS $+0.5 \mathrm{mg} / 1 \mathrm{IBA}$ in third weeks of culture.

(d) Acclimatized regenerated plants of three months old.

same medium but highest numbers of micro shoots were observed to be induced from nodal explants (Fig. 1b). Combinations of BAP with NAA or IAA were not found to be suitable than BAP alone for shoot induction (Table I) and combinations of Kn with NAA or IAA were also not found to be suitable for shoot induction (Data were not shown). In different medicinal plant, it was also observed that multiple shoots were found by using different concentration of cytokinin with auxins by other researchers (Faisal et al., 2003; Mallikadevi et al., 2008; Sahoo and Debata, 1998; Usha et al.,2007; Wawrosch et al., 2001).
$82.4 \%$ regenerated shoots rooted (Fig. 1c) when cultured individually on root induction medium consisted of halfstrength MS medium with $0.5 \mathrm{mg} / \mathrm{l}$ IBA (Table II). Use of auxins singly or in combination for rooting was also reported by different authors (Baskaran and Jayabalan 2005; Bhadra et al., 2009; Hassan and Khatun, 2010; Sivakumar and Krishnamurthy, 2000).

After four weeks the rooted shoots were transferred to pots. None of the plantlets were survived when directly transferred from rooting medium to the pot under natural conditions. About 85 percent of the transplanted plants of Coccinea cordifolia (Linn.) Cogn. survived if the plants in the rooting culture tubes were kept in normal room temperature for seven days before transplantation in pots and reared for three weeks. The plantlets were reared under semi-controlled temperature $\left(30 \pm 2^{\circ} \mathrm{C}\right)$ and light (1500 lux) in a chamber with 80 percent humidity. During this period of acclimation shoots elongated, leaves expanded and turned deep green and healthier (Fig. 1d ).

After three weeks, plants were transferred to an open place and gradually acclimated to outdoor conditions, where 85 percent plants were survived. The technique described here

Table II : Effect of different auxins (IBA, NAA and IAA) on root induction in regenerated shoots of Coccinea cordifolia (Linn.) Cogn. on half strength MS

\begin{tabular}{|c|c|c|c|c|}
\hline \multicolumn{3}{|c|}{ Growth regulators $(\mathrm{mg} / \mathrm{l})$} & \multirow{2}{*}{$\begin{array}{l}\% \text { of shoots } \\
\text { producing } \\
\text { roots } \\
( \pm \mathrm{SE})\end{array}$} & \multirow{2}{*}{$\begin{array}{l}\text { No. of } \\
\text { roots/shoot } \\
( \pm \mathrm{SE})\end{array}$} \\
\hline BAP & NAA & IAA & & \\
\hline 0.5 & & & $82.4 \pm 1.16$ & $8.8 \pm 0.65$ \\
\hline 0.75 & & & $67.2 \pm 1.53$ & $6.8 \pm 0.65$ \\
\hline 1.0 & & & $63.2 \pm 1.46$ & $5.2 \pm 0.76$ \\
\hline 1.5 & & & $61.0 \pm 0.10$ & $4.6 \pm 0.72$ \\
\hline & 0.5 & & $77.8 \pm 1.85$ & $5.2 \pm 0.76$ \\
\hline & 0.75 & & $64.2 \pm 1.53$ & $4.0 \pm 0.63$ \\
\hline & 1.0 & & $62.0 \pm 0.71$ & $3.8 \pm 0.59$ \\
\hline & 1.5 & & $59.4 \pm 1.08$ & $2.2 \pm 0.71$ \\
\hline & & 0.5 & $65.2 \pm 1.16$ & $4.8 \pm 0.65$ \\
\hline & & 0.75 & $61.4 \pm 0.75$ & $3.6 \pm 0.96$ \\
\hline & & 1.0 & $62.6 \pm 0.93$ & $2.6 \pm 0.72$ \\
\hline & & 1.5 & $48.2 \pm 0.71$ & $2.2 \pm 0.63$ \\
\hline
\end{tabular}

Data were recorded after four weeks of culture. Results are mean $\pm \mathrm{SE}$ of 15 replications. 
appears to be readily adaptable for large scale plant regeneration and plantation for sustainable use.

\section{Acknowledgement}

The authors are indebted to Mr. Jasim Uddin Chowdhury, Ex. Director, BCSIR Laboratories, Dhaka and. Grateful acknowledgement is also due to Professor Elias Khan, Principal, Savar College, Savar, Dhaka for their kind permission, sincere suggestions and moral support during research work.

\section{References}

Ajithkumar D and Seeni S 1998. Rapid clonal multiplication through in vitro axillary shoot proliferation of Aegle marmelos (L) Corr., A Medicinal Tree. Plant Cell Rep. 17: 422-426.

Anonymous 1989. The Wealth of India: Raw Materials. CSIR, New Delhi, India.Vol. VIII: Ph-Re, pp 162-164.

Baskaran P and Jayabalan N 2005. An efficient micropropagation system for Eclipta alba - a valuable medicinal herb. In Vitro Cell. Dev. Biol. Plant. 41: 532-539.

Bhadra SK, Akhter T and Hossain MM 2009. In vitro micropropagation of Plumbago indica L. through induction of direct and indirect organogenesis. Plant Tissue Cult. and Biotech. 19(2): 169-175.

Faisal M, Ahmad N and Anis M 2003. Shoot multiplication in Rauvolfia tetraphylla L. using thidiazuron. Plant Cell Tiss. Organ. Cult. 80: 187-190.

Ghani A 2003. Medicinal Plants of Bangladesh with Chemical Constituents and Uses. 2nd Ed. (Asiatic military press, Dhaka, 1000) pp 350-351.

Hassan AKMS and Roy SK 2005. Micropropagation of Gloriosa superba L. through high frequency shoot proliferation. Plant Tissue Cult. and Biotech. 15(1): 67-74.

Hassan AKMS. and Khatun R 2010. Regeneration of Ficus glomerata Roxb., using Shoot tips and Nodal explants. Bangladesh Journal of Botany. 39(1): 47-50.

Lui Z and Li Z 2001. Micropropagation of Camptotheca acuminata Decaisne. from axillary buds, shoot tips and seed embryos in tissue culture system. In Vitro Cell Dev. Biol. Plant. 37: 84-88.
Martin KP 2002. Rapid propagation of Holostema ada-kodien Schult. a rare medicinal plant, through axillary bud multiplication and indirect organogenesis. Plant Cell Rep. 21: 112-117

Martin KP 2003. Plant regeneration through somatic embryogenesis on Holostema ada-kodien Schult. a rare medicinal plant. Plant Cell Tiss. Orga. Cult. 72: 79-82.

Mallikadevi T, Senthilkumar P and Paulsamy S 2008. In vitro regeneration of the medicinal plant, Plumbago zeylanica $\mathrm{L}$. with reference to a unique population in maruthamalai, the western ghats, India. Plant Tissue Cult. and Biotech. 18(2): 173-179.

Murashige T and Skoog F 1962. A revised medium for rapid growth and bioassays with tobacco tissue culture. Physiol. Plant. 15 : 473-479.

Prakash E, Khan SSV, Reddy PSSP and Rao KR 1999. Regeneration of plants from seed-derived callus of Hybanthus enneaspermus L. Muell., a rare ethnobotanical herb. Plant Cell Rep. 18 : 873-878.

Sahoo S and Debata BK 1998. Micropropagation of Plumbago zeylanica Linn. Journal of Herbs, Spices \& Medicinal Plants. 5(4): 87-93.

Sivakumar G and Krishnamurthy KV 2000. Micropropagation of Gloriosa superba L.- an endangered species of Asia and Africa. Current Scence. 78(1): 30-32.

Usha PK, Benjamin S, Mohanan KV and Raghu AV 2007. An efficient micropropagation system for Vitex negundo L., an important woody aromatic medicinal plant, through shoot tip culture. Research Journal of Botany. 2(2): 102-107.

Wawrosch C Malla R R and Kopp B 2001. Clonal propagation of Lilium nepalense D. Don, a threatened medicinal plants of Nepal. Plant Cell Rep. 10: 457-460.

Manuscript received on 17 October 2011; revised on 25 January 2012; accepted on 26 February 2012. 